\title{
Translator-Training Institutions
}

Monique Caminade and Anthony Pym

Published in Encyclopedia of Translation Studies, Ed. Mona Baker, London \& New York: Routledge, 1998, 280-285.

Translators and interpreters have long been trained informally, basically through trialand-error, unstructured apprenticeship arrangements, or any of the various translating activities that accompany the study of a foreign language. Translator-training institutions, however, can be understood as organisational structures designed specifically for this task, with a certain permanence and internal power relationships. Most such institutions are now university departments, faculties or relatively independent university institutes, although others are run by government bodies, international organisations, professional associations, large employers or private schools. Most of these institutions depend on wider structures within the one society (state or private education systems) and thus vary in accordance with local contexts. Some structures, however, cross several societies and thus allow a certain typology to be based on various 'generations' of institutions.

The following survey will be from an international perspective, focusing on the generations of translator-training institutions and the dramatic rise in their number since the mid-twentieth century. Brief consideration will also be given to the institutional location of certain pedagogical translation theories.

\section{Historical background}

The institutional training of translators and interpreters is a relatively new phenomenon. Talk of historical 'schools' of translation has little to do with people actually learning a profession. A certain degree of institutionalisation certainly ensued when translators were associated with Islamic colleges of the classical period, with cathedral chapters as in twelfth-century Toledo, or with court scholarship from the thirteenth century. But such institutions mainly concerned groups of translators working on similar texts. If there was any specific training, it seems more likely to have been through informal meetings or apprenticeships, with younger translators working under the guidance of masters. Even then, the relative absence of full-time professional translators means training was likely to have been in particular subject matters, with translation used as a mode of study or as an occasional means of financial survival. 
A certain political interest in this field necessarily evolved with the great European colonisations. Rudimentary translator-training programmes might be seen in the practice of taking natives back to the metropolis to turn them into bilingual intermediaries. Yet the colonial emphasis was more on regulating a suspect profession than actually producing professionals. Significantly, the numerous Spanish laws that stipulated the rights and duties of interpreters in the American colonies said nothing about how anyone actually became an interpreter.

The state institutionalisation of translator training might be dated from 1669, when the Colbert decree in France arranged for the training of French-born students as interpreters for Turkish, Arabic and Persian, leading to the founding of the Constantinople school. In 1754 the empress Maria Theresa founded the Oriental Academy, which provided a number of orientalists and interpreters to the Habsburg court over the years (Delisle and Woodsworth eds 1995: 270-271). Beyond Europe, some of the initial moves could be seen as a reaction to colonial expansion, at once affirming oppositional identity and facilitating the transfer of knowledge. The large Egyptian translation school now known as Al-Alsun was established in 1835. In China, at the beginning of the nineteenth century, a group known as Yangwu, comprising high government officials dealing with Foreign Affairs, created institutions for the training of translators in areas like shipbuilding and weapons manufacture. From 1896 Yan Fu, at that time principal of the Northern Chinese Naval Academy, supervised several translation schools operating under central and local government authority. Further information on these and similar institutions may be gained from the historical section of this encyclopedia.

Within Europe, the drive to create national cultures could underlie certain literary training programmes, as was the case of the apprentice scheme set up in Finland in 1831. Yet the need to extend and control international relations was a more powerful consideration. Several measures were undertaken directly by the corresponding state institutions. Although the diplomatic services were only informally associated with specialised interpreter training (Harris 1993, Bowen 1994), the Humboldt University in Berlin did have a translator-training programme for diplomats from 1884 through to 1944. In Spain the Ministry of Foreign Affairs controlled sworn translators and still organises the corresponding state exams, emphasising the translation of official documents. Traces of this tradition are still found in many Spanish-American universities, where translator training is dominated by legal work and sworn translation: in Uruguay, the national university's School of Law has issued the degree of Public or Sworn Translator since 1855 (Sainz 1993). The need for specially trained legal translators was also of particular concern to properly twentieth-century institutions. The Copenhagen Business School trained students in sworn translation and interpreting 
from 1921, and the Paris Institute for Comparative Law has been training legal translators since 1931.

\section{Rise in the mid-twentieth century}

A more generalist approach would appear to date from several west-European institutions that were mainly focused on interpreter training and enjoyed a large degree of independence with respect to non-vocational university structures. Such institutes were established in Heidelberg (1930), Geneva (1941) and Vienna (1943). Elsewhere, as at the Moscow Linguistic University (1930), translator training was more explicitly integrated into independent foreign-language institutes, a model that still pertains in Russia, China and some eastern-European countries.

Institutionalisation took a new turn in the years immediately following the second world war, when the victorious powers set about establishing their international regime through the microphones and headsets of simultaneous interpreters. Independent university-level institutions, once again with a strong emphasis on interpreting, were quickly established in the border regions of the Third Reich: in Graz (1946), Innsbruck (1946), Germersheim (1947) and Saarbrücken (1948), closely followed by Georgetown in the United States (1949). These institutions were associated with the cause of building peace in what was then the most problematic part of the world.

A further generation appeared in the 1950s, when French initiatives laid the foundation of European unity and French diplomacy sought importance on the world stage. Following the founding of the Fédération Internationale des Traducteurs (FIT) in Paris in 1953, the École Supérieure d'Interprètes et de Traducteurs (ESIT) and the Institut Supérieur d'Interprétation et de Traduction (ISIT) were both set up in Paris in 1957. These institutes privileged interpreting, particularly conference interpreting, which was the high-profile face of the profession.

Not wholly by chance, the French language then dominated the first international network of institutions, the Conférence Internationale des Instituts Universitaires de Traducteurs et Interprètes (CIUTI), which met informally from 1960 and was officially established in 1964 at the initiative of the institutions in Geneva, Heidelberg, Germersheim, Paris-ESIT, Saarbrücken, Trieste and Vienna. The ostensible aim of the CIUTI was to ensure the quality of graduates from its member institutions. Yet its implicit function, to a certain extent deducible from the nature of the member institutions, was and remains to extoll a west-European model of translator training based on relatively independent institutes that are exclusively concerned with translation (as opposed to language teaching) and emphasise the training of conference interpreters. The east-European integration of translation and language learning was quietly devalued, as were the professional standards of university departments of 
modern languages and literatures. Significantly, the CIUTI institutions differed from nineteenth-century models in that they were not directly dependent on government initiatives. The people running and teaching in them were often professional interpreters; the profession itself had taken to setting its own standards and defining its own objectives.

These developments inevitably led to minor conflict with the established nonvocational academisation of translation. One of the results was a certain belligerence in the pedagogical approaches formulated in the early CIUTI tradition. Danica Seleskovitch's théorie du sens, which assumed doctrinal proportions at the Paris ESIT, heroically championed professional interpreting as the starting point for all translation theory (see \#INTERPRETATIVE APPROACH\#). Such a theory effectively stated the case for an independent translator-training institution focused on interpreting and run by the profession itself. A different strategy was adopted in Saarbrücken, where the linguistic models of Wilss emphasised technical expertise as the vocational side of applied linguistics. The functionalist theory pronounced by Vermeer at Heidelberg in the 1980s gave greater priority to the professional translator's situation, yet it also fought the cause of the independent translation institute as opposed to narrowly philological or literary programmes. All these theories offered solutions to an institutional conflict.

It would be wrong, however, to suppose that the CIUTI institutions are all of the same mold. The French members basically offer two-year specialised second-cycle (master's) programmes, with students gaining their language competence through a first degree completed elsewhere. The German institutions, on the other hand, are based on a four-year structure where language learning is inevitably mixed with specialised courses in translation and interpreting. Not surprisingly, the four-year structure has proved harder to justify in terms of institutional independence from other university departments. The result has been considerable theoretical debate and occasional balancing acts between the technical-linguistic tradition and a purpose-oriented pragmatism. One outcome would appear to be the German theories that now envisage an extension of the translator's role into general intercultural expertise or consulting functions (see \#DIDACTICS OF TRANSLATION\#), since this is an effective way of justifying a four-year structure that ostensibly excludes language learning. The prestigious French institutions, which still have second-cycle programmes, continue to promote a more restrictive vision the interpreter/translator's specialist role.

Despite these internal differences, the CIUTI has proved relatively successful. The organisation has some twenty-one member institutions (in 1995), all of them in western Europe and North America, and members organise student exchange programmes between themselves. Some of the older institutes are now very large, with over a thousand students. The implicit CIUTI principles are also widely respected among 
newly created institutions, to the extent that some of the original members have directly or indirectly produced partial clones. The prestigious Ottawa school, founded in 1970, looked towards Paris, and the ESIT has strong ties with institutions in places like Buea and Tangiers, both founded in 1986. Whereas they had once served colonial institutions, translators and interpreters created their own institutions with their own relatively independent postcolonial relationships.

\section{Convergence of vocational and academic criteria}

As much as the west-European and American institutions established before the 1980s may still be legitimised on the level of theory, their basic precept of vocationally based independence has been radically challenged by the changing nature of tertiary education. In numerous countries, a series of reforms in the 1980s and early 1990s removed many barriers between vocational and academic education in virtually all fields. As the various technical or professional-training institutions were integrated into national university systems, translator-training programmes could no longer lay claim to vocationally based independence. Some of the CIUTI institutions were integrated into university structures: the ESIT, for example, was associated with the Sorbonne through a law of 1984; many of the German institutions found their academic location in applied linguistics. In Spain, translator training was carried out in three-year vocational-training programmes right through to 1992, when a national law allowed the creation of four-year university faculties of translation and interpreting. This general integration has had numerous far-reaching consequences.

First, most obviously, there has been a dramatic rise in the number of universitylevel institutions offering degrees or diplomas specifically in translating or interpreting (see graph). From 49 in 1960 then 108 in 1980, the global number had risen to at least 250 in 1994 (Caminade and Pym, 1995). The reasons for this rapid expansion lie most obviously in the market demand for translators, although the worldwide growth in youth unemployment has also created a demand on the part of students in search of jobs. 
Translator-Training Institutions

Frequency of creation over five-year periods

(sample of 244 institutions from all countries)

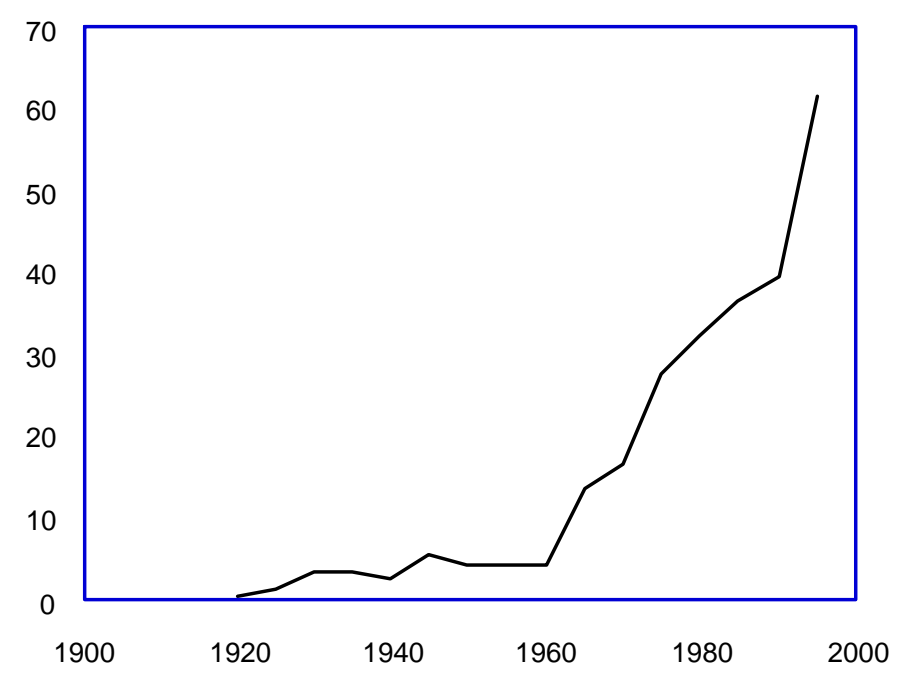

Since the major change came from general university systems rather than from within translator-training institutions, the vast majority of the programmes created in the early 1990s were actually within established university departments of language and literature or were organised on an interdepartmental basis. In terms of numbers of institutions, this development has effectively superseded the mid-century emphasis on profession-based independent structure. Most of the more recent programmes now involve shorter, second-cycle (master's) studies designed to add specific competences to general skills that students have obtained elsewhere.

Having thus entered the academic sphere, translator training has become loosely attached to an academic discipline, translation studies, which in some circumstances gives the pedagogical programmes greater legitimacy within the university environment. This recent academisation has involved the development of third-cycle (doctoral) programmes leading on from strictly vocational studies, sometimes with a focus on contrasted empirical research. It has also inevitably led to greater contact with the non-vocational translation studies occasionally associated with university departments of linguistics or comparative literature. The very disciplines that had been distanced in the heroic days of translator training now tend to be integrated into allembracing theories and pedagogical approaches; theorists thus stress the variety of perspectives that can be brought to bear on translator training.

The rapid institutional expansion in translator training has provided a demand for publications and academic jobs at a time of relative stagnation in other university departments, especially those of comparative literature. Various literary theorists have consequently taken a cultural turn towards translation, sometimes with the pretence of liberating translators from exploitive ideologies, more often claiming that translation 
studies should have room for them too. In institutional terms, the primary change has nevertheless been the massive growth in translator training rather than translation theory.

The large established translator-training institutions have occasionally adapted to these changes. In seeking a greater degree of modularisation (basically by breaking long degree programmes into shorter diploma programmes), some have countered the rigidity and high attrition rates that ensue from having vast numbers of students undertake four-year blocks. In effect, such modularisation may have helped the large institutions function like the smaller and shorter programmes typical of the early 1990s.

There remains, however, a serious concern with professional standards. In order to protect the quality of their graduates, established institutions tend to associate the newer programmes with a certain lack of competence, occasionally accusing them of teaching languages instead of translation, of engaging in idle theory, or of simply following fashion. Although some of these accusations are undoubtedly true, the question of standards is by no means clear cut. From 1964 the Conference Interpreting Service of the European Commission has been training its own interpreters, and professional translators and interpreters can still easily get by without any degree in translation. Further, quality-control institutions have more recently been created on the national level, particularly in countries that have no CIUTI members. In Sweden, the Institute for Interpretation and Translation Studies was founded in 1986 with a government mandate according it responsibility for all regular translator training in the country. The Australian National Accreditation Authority for Translators and Interpreters regularly evaluates both translator-training programmes in Australia and the overseas qualifications of translators working in the country. In Britain the Institute of Linguists has been organising public examinations in the field of translation and public-service interpreting since 1989. The Spanish Association (Conferencia) of University Centres and Departments of Translation and Interpreting was created in 1995. Several national translators' associations also take a direct interest in translator training, as is the case in Germany, Britain and the United States.

To summarise, the trend since the late 1980s has been towards shorter more fragmented programmes that are increasingly integrated into wider university structures and may conform to national rather than international criteria. There even seems to be less insistence on a strict focus on translation (the newer institutions often exchange students with universities that have no particular specialisation in this field). The sum result is greater diversity, flexibility and in some cases an enhanced capacity to respond to social needs. Programmes in community interpreting, sometimes at a paraprofessional level, have been developed independently of the more established institutions, notably in countries like Sweden and Australia. These general trends augur for increased diversity rather than global conformity to one set of standards. 
The immediate future of translator training will no doubt be marked by further growth in geographical areas that currently have few formal programmes. India, SouthEast Asia and China have trade statistics that would seem to warrant greater specific competence in this field. Japan is a case where future expansion might be expected to build on the established focus on short-term interpreting programmes. There is nevertheless cause for caution on the global level. Recent years have seen the termination of translator-training programmes in Besançon (France), Perth (Australia), Rutgers and Delaware (United States), as well as the abolition of non-vocational translation studies in Amsterdam and serious threats to the Saarbrücken institute. More significantly, detailed analysis suggests that the global expansion of the late 1980s may have peaked in 1992-93. The boom could have been based on a euphoric projection of market demands rather than on the real creation of long-term full-time employment for translators and interpreters.

See also \#DIDACTICS OF TRANSLATION\#.

Further reading: Arjona-Tseng 1991; Caminade and Pym 1995; Gile 1995; Gold 1975; Harris Forthcoming; Park 1993; SIIT 1993. Surveys of particular programmes appear regularly in the journals Language International and The Translator.

Monique Caminade and Anthony Pym

\section{BIBLIOGRAPHY}

Arjona-Tseng, Etilvia (1991) 'The Creation of a Graduate Institute for Translation and Interpretation Studies in the Republic of China on Taiwan', in Mladen Jovanovic (ed.) Translation: A Creative Profession: 12th World Congress of FIT. Proceedings, Belgrade: Prevodilac. 506-26.

Caminade, Monique, and Pym, Anthony (1995) Annuaire mondiale des formations en

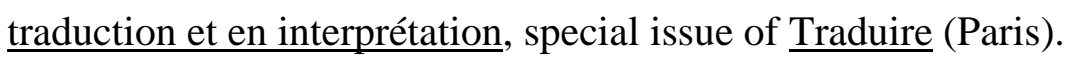

Bowen, Margareta (1994) 'Negotiations to end the Spanish-American War', in Mary Snell-Hornby et al. (eds) Translation Studies. An Interdiscipline, Amsterdam and Philadelphia: John Benjamins. 73-81.

Delisle, Jean and Judith Woodsworth eds. 1995. Translators through History. Amsterdam/ Philadelphia: John Benjamins/UNESCO. 
Gile, Daniel (1995) Basic Concepts and Models for Interpreter and Translator Training, Amsterdam and Philadelphia: John Benjamins.

Gold, D. L. (1975). 'Planning a school for translators and interpreters', Babel 21(3): 107-08.

Harris, Brian (1993) 'Un intérprete diplomático inglés en el siglo XIX en Japón', Livius. Revista de Estudios de Traducción 3: 115-136.

Harris, Brian (Forthcoming) World Directory of Translation and Interpretation Teaching, Amsterdam and Philadelphia: John Benjamins.

Park, William M. (1993) Translator and Interpreter Training in the USA: A Survey, Second Edition. American Translators Association.

Sainz, María Julia (1993) 'The role of translation in Uruguay', Language International 5(6): 32-34.

SIIT - Servicio Iberoamericano de Información sobre la Traducción (1993) Repertorio de instituciones relacionadas con la traducción y la interpretación en los países de habla hispana y portuguesa, Beccar (Argentina): SIIT. 